\title{
JOURNAL.RU
}

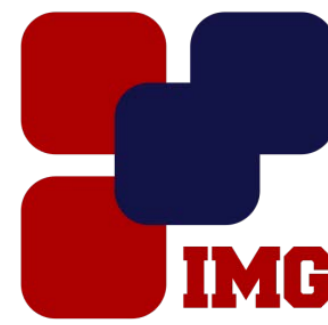

Ivanoy
Management
GRoup

Краснорепова И.В., Краснорепова О.В

Федеральное государственное бюджетное образовательное учреждение высшего образования «Национальный исследовательский Мордовский государственный университет им. Н. П. Огарёва"

Саранск, Россия

doi: 10.18411/lj-30-11-2016-3-09

idsp 000001:lj-30-11-2016-3-09

\section{Банковский маркетинг как инструмент диверсификации линейки продуктов и услуг кредитнымиучредениями}

\section{Аннотация}

В данной статье раскрывается актуальность и необходимость использования комплексного маркетинга в банковском учреждении, на примере AО «Россельхозбанк» описаны основные инструменты маркетинга, используемые коммерческим банком, выявлены основные недостатки, присущие формированию и развитию маркетинговой стратегии, предложены рекомендации по эффективному становлению комплекса маркетинга в банке.

Ключевые слова: банковский маркетинг, маркетинговая деятельность, банковский продукт, эффективность маркетинговой деятельности

В современных условиях рынок банковских продуктов и услуг состоит из большого количества участников, поэтому прослеживается тенденция ужесточения конкурентной борьбы среди коммерческих банков на российском рынке и, следовательно, нарастает борьба за клиента, посредством использования новых продуктов и услуг, а также формирования оптимальных путей их предоставления [1, с. 106].

В условиях усиливающейся конкуренции, быстрого насыщения рынка отдельной услугой, предоставляемой кредитными организациями, конкуренты активно заимствуют друг у друга способы продвижения продуктов и услуг $[3, \mathrm{c}$. 211]. Поэтому перед банковскими институтами возникает потребность во внедрении новых услуг и обеспечении достаточно высокого уровня их конкурентоспособности. Важную роль в этом процессе играет банковский маркетинг, активное же внедрение которого должно способствовать повышению конкурентоспособности предлагаемых банками продуктов и услуг. 
Банковский маркетинг в силу его специфики представляет собой особую отрасль маркетинга. Усиление конкуренции и увеличение требований клиентов к банковским услугам приводят к тому, что все большее число банков обращаются к маркетингу, разрабатывают стратегические маркетинговые планы, чтобы адаптироваться к изменениям внешней среды и обеспечить успех в конкурентной борьбе.

$\begin{array}{llcr}\text { Исследование действующей практики банковского } & \text { маркетинга } \\ \text { осуществлялось на материалах акционерного общества «Российский }\end{array}$ сельскохозяйственный банк» - одного из крупнейших банков в России. АО «Россельхозбанк» создан в 2000 году в целях развития национальной кредитнофинансовой системы агропромышленного сектора и сельских территорий Российской Федерации.Сегодня он является универсальным коммерческим банком, предоставляющим все виды банковских услуг и занимающим лидирующие позиции в финансировании агропромышленного комплекса России. В ходе своей деятельности исследуемый банк использует элементы банковского маркетинга для обеспечения конкурентоспособности предлагаемых банковских услуг на рынке Мордовии.

АО «Россельхозбанк» позиционирует себя как универсальный финансовый институт и, соответственно, предлагает широкий перечень банковских продуктов и услуг, включая расчетно-кассовое обслуживание, зарплатные проекты, депозиты, финансирование внешнеэкономической деятельности, VIP-обслуживание для состоятельных частных клиентов и др.

Приоритетными направлениями банковских продуктов и услуг являются:

- обслуживание корпоративных клиентов;

- работа с физическими лицами (розничный бизнес);

- инвестиционная деятельность - операции на финансовых рынках [2].

В целях обеспечения конкурентоспособности «Россельхозбанк» использует в своей деятельности следующие элементы банковского маркетинга:

- исследование потребителей и рынка;

- реклама;

- «паблик рилейшнз»;

- формирование каналов распределения;

- обеспечение обратной связи с потребителем.

Ежегодно банк внедряет новые продукты в свою деятельность. В 2016 г. Россельхозбанк запустил новый вклад «Амурский тигр» с ежемесячной выплатой процентов на счет платежной карты. Данный продукт является самым высокодоходным в депозитной линейке Банка среди вкладов с ежемесячной выплатой процентов - при его открытии на срок 395 дней процентная ставка составит 7,60\% годовых, 540 дней - 7,95\%, 730 дней - 7,90\%. Для микробизнеса Банк внедрил новые кредитные продукты, такие как «Быстрое решение», «Микро» и «Оптимальный». Среди актуальных опций продуктов хотелось бы отметить увеличение срока кредитования, возможность поэтапного 
финансирования и быстрое рассмотрение заявок. С сентября 2016 г. банк ввел в линейку вкладов для физических лиц новый продукт - «Пенсионный доход». Одним из преимуществ продукта является предоставляемый клиенту выбор способа выплаты процентов: ежемесячная капитализация или перечисление процентов на счет в Банке.На рисунке 1 представлена динамика внедрения новых продуктов и услуг в деятельность «Россельхозбанка».

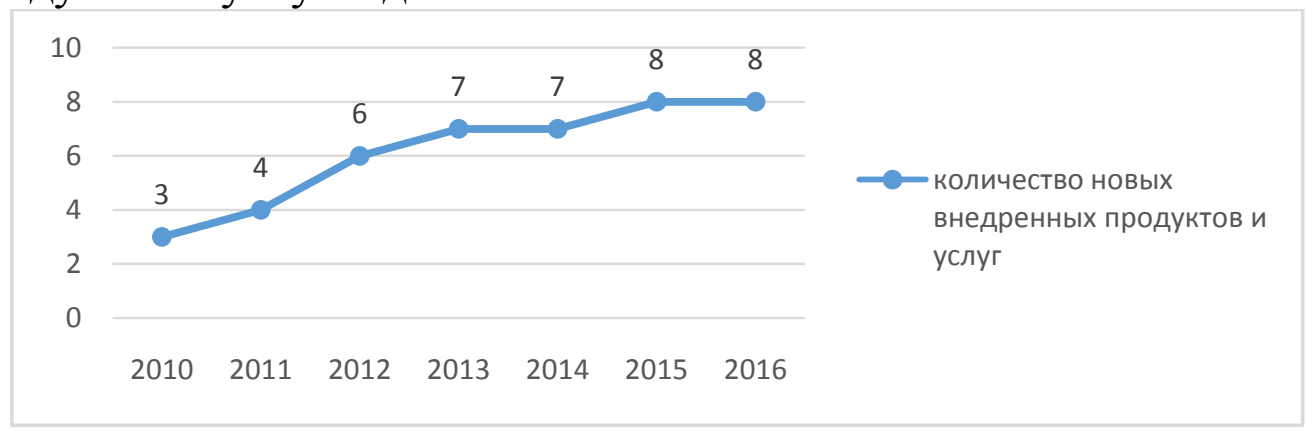

Рис. 1 - Динамика количества новых продуктов и услуг, внедренныхх в АО «Россельхозбанк»за 2010-2016 г.

Отметим также, что АО «Россельхозбанк» в маркетинговой деятельности использует инновационные методы продвижения своих банковских услуг, а именно Интернет-маркетинг, который в последние годы становится наиболее популярным способом продвижения и продажи банковских продуктов. Так, по итогам 2015 г. можно говорить о тенденции роста осведомленности населения об удаленных каналах обслуживания (УДО), чему активно способствовал АО «Россельхозбанк», а также другие организации, предоставляющие услуги для совершения платежей и переводов, путем проведения различных акций и рекламных кампаний, привлекающих потребителей выгодными условиями и удобством совершения операций.

Данные действия принесли свои плоды: в результате предпринятых усилий в течение 2015 года наблюдался постепенный рост осведомленности среди населения об УКО - в частности, об Интернет-банке и Автоплатежах (рисунок 1).

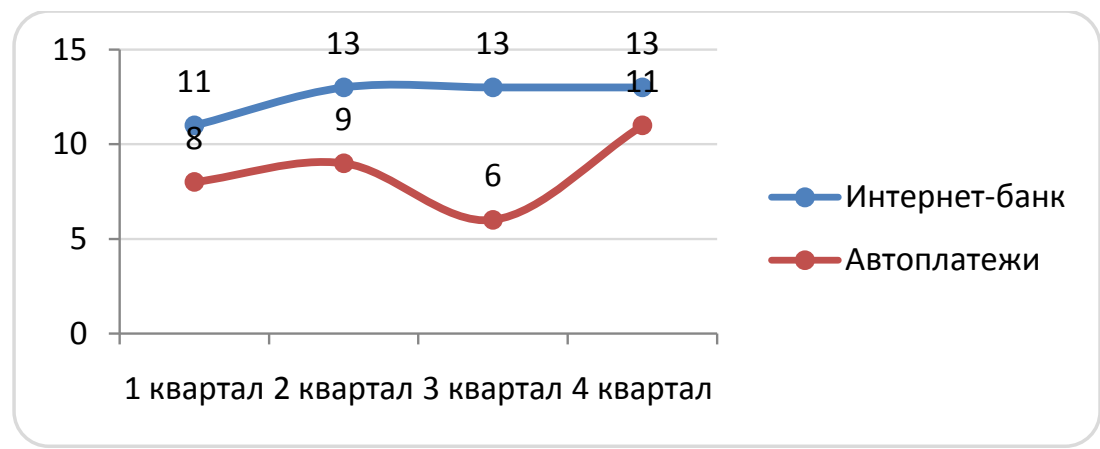

Рис.2 - Динамика осведомленности клиентов АО «Россельхозбанк» об инноваџионных инструментах Интернетмаркетинга, \%

При этом наиболее распространенными платежами, осуществляемыми посредством УКО в АО «Россельхозбанк», являются платежи за сотовую связь, жилищно-коммунальные услуги (далее ЖКХ), Интернет/платное ТВ и погашение задолженности. Растет текущее пользование Интернет-сервисами АО «Россельхозбанка» (с 9\% до 11\%). На этом фоне снижается совершение 
платежей через Кассу (оплата ЖКХ, Интернета и платного телевидения, штрафов и налогов, образовательных услуг, а также совершение денежных переводов).Необходимо обратить внимание, что вместе с ростом осведомленности потребителей снижаются барьеры, «мешающие» пользованию удаленными каналами.

Важно также отметить ряд других позитивных тенденций использования Интернет-маркетинга в АО «Россельхозбанке»: постепенно снижается общее ощущение сложности совершения платежей через удаленные каналы, а также значительно менее выражено опасение, что совершение платежей через УКО небезопасно. Это свидетельствует о постепенном привыкании потребителей к мысли, что, научившись пользоваться УКО, можно проводить необходимые операции по оплате, не беспокоясь, что платеж не пройдет, или будут другие негативные последствия.

Для усиления позитивных тенденций (снижения «барьеров» у потребителей к пользованию УКО), необходимо дальнейшее продвижение удаленных сервисов АО «Россельхозбанка» с акцентом на их преимуществах над «привычными» способами оплаты.

Рост знания альтернативных способов совершения оплаты, и постепенное снижение «барьеров» отражаются на поведении потребителей $\mathrm{AO}$ «Россельхозбанка» - растет фактическое пользование удаленными и понемногу снижается пользование традиционными каналами обслуживания. Данный тренд наблюдается практически во всех потребительских сегментах, в том числе и в наиболее «консервативном» сегменте пенсионеров, которые вместе со всеми остальными начинают осознавать преимущества УКО.

Благодаря активному продвижению банками удаленных каналов оплаты, наблюдается не только тенденция роста осведомленности потребителей об альтернативных способах совершения платежей и переводов, но и фактическое изменение его поведения, в частности - постепенный уход от кассы, как традиционного способа обслуживания.

Поскольку основной сегмент у ОАО «Россельхозбанк» юридические лица, поэтому система продвижения товаров для юридических лиц имеет свои особенности. Массовую рекламу услуг банка будет нецелесообразно использовать, потому что она не будет направлена на сегмент. Денежные средства, выделенные в данном случае на продвижении услуг, не будут переведены в клиентов и, соответственно, в будущую прибыль. Поэтому ОАО «Россельхозбанк» использует специфические каналы для рекламы. Это различные печатные издания бизнес тематики, основной долей которых являются бизнесмены и юридические лица, реклама на радио внутри бизнес сводок, реклама на тематических мероприятиях. В дополнение к этому сотрудники клиентского отдела также осуществляют «личные продажи». В этом случае выясняются предприятия, которые не пользуются услугами других кредитных организаций, далее им предлагаются услуги ОАО «Россельхозбанк» либо по вкладам, либо по кредитованию. 
Говоря в целом о стратегии маркетинга в АО «Россельхозбанке», стоит отметить, что наиболее сильными сторонами системы управления маркетингом в Банке можно выделить: систему стратегического планирования и контроля, формирование ассортимента банковских продуктов и услуг, рыночную ориентацию персонала, использование инновационных методов продвижения услуг. К слабым сторонам системы управления маркетингом можно отнести: функционирование маркетинговой информационной системы; осуществление контроля над маркетинговой деятельностью; организацию управления качеством.

Следует отметить, что, активно внедряя в свою деятельность передовые технологии АО «Россельхозбанк» используют разные маркетинговые средства, при этом маркетинг не получил применения в целостной системе управления банком в широком стратегическом плане. Иными словами, в АО «Россельхозбанк» используются отдельные элементы маркетинговых стратегий, но при этом не ведется учет экономической эффективности маркетинговых элементов и не оценивается перспектива развития достигнутых целей.

Если рассмотреть зарубежную банковскую практику, то можно отметить, что здесь постоянно уделяется внимание конкурентной стратегии. Освоение этой маркетинговой стратегии в России происходит на протяжении длительного периода времени, и оно не успело ознаменоваться успехом.

Исходя из названных особенностей маркетинговой деятельности в АО «Россельхозбанк», основной проблемой в исследуемом банке является проблема формирования и оценки реализации маркетинговой деятельности. На этапе формирования маркетинговой стратегии банковские специалисты некорректно формируют цели стратегии, в связи с этим отсутствует адекватное сопоставление между задачами стратегии и потенциальными возможностями банка. Разработчики стратегии также не уделяют внимания качеству исполнения стратегических задач со стороны банковского персонала. Это связано с тем, что, какправило, маркетинговый отдел не оказывает директивного влияния на сотрудников банка, а в случае вмешательства руководства банка в исполнение стратегических задач, может быть снижена- эффективность управления, так как на руководство при этом возлагается переориентация управленческой деятельности.

Совокупность вышеперечисленных проблем в АО «Россельхозбанк» является причиной отсутствия комплексной разработки и реализации маркетинговой стратегии. Для того чтобы разработать и реализовать эффективную банковскую маркетинговую стратегию в Банке, следует придерживаться следующих принципов:

1) маркетингом должны заниматься компетентные специалисты. В данном случае речь идёт о совместной работе персонала банка с маркетологами, так как персонал - внутренняя среда банка, а маркетологи - внешняя;

2) стратегия должна содержать в себе чёткие цели и адекватные задачи; 
3) контроль должен стать главной функцией в стратегии, так как он обслуживает все остальные стратегические функции от начала и до конца;

4) следует соблюдать обратную связь «маркетолог - персонал - клиент...»;

5) помимо оценки внешней и внутренней среды, необходимо изучать и принимать опыт маркетинговых стратегий других банков;

6) необходимо разработать комплексную программу повышения лояльности потребителей банковских услуг;

7) необходимо усовершенствовать имеющуюся продуктовую линейку банка, тарифную и процентную политики в соответствии с новыми экономическими условиями.

Использование данных рекомендаций по формированию и развитию маркетинговой деятельности поможет сформировать эффективную стратегию АО «Россельхозбанк» в области банковского маркетинга. При этом стоит отметить, что организация маркетинговой деятельности в банковской сфере не должна сводиться лишь к активизации рыночной политики и применению некоторых элементов комплекса маркетинга. Развитие маркетинговой деятельности в АО «Россельхозбанк» должно влиять на изменение образа мышления банковских работников и изменение организационной структуры банка.

\section{Литература}

1. Мальчик М.В. Банковский маркетинг в конкурентной среде/ М.В. Мальчик, С.И. Коваль//Научные записки Нац. ун-та «Острожская академия». - Серия «Экономика». - Вып. 24 - 2013. - 306 с.

2. Официальный сайт АО «Россельхозбанк» [Электронный ресурс] режим доступа: http://www.rshb.ru/about/

3. Панкрутин А.П. Маркетинг: учебник.- 3-е изд. / А. П. Панкрутин.М.: Омега-Л, 2015.- 656 с.

4. Русских, А.В. Типы и особенности маркетинга- банковских услуг / А.В. Русских // Российское предпринимательство. - 2013. - №10 (232). - C.35 - 40. 